Archived version from NCDOCKS Institutional Repository http://libres.uncg.edu/ir/asu/

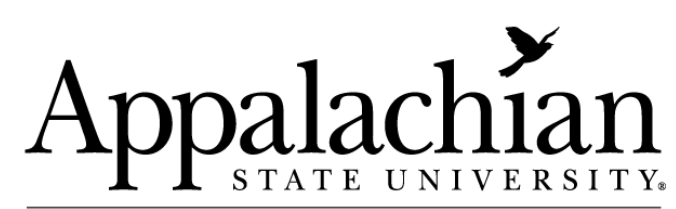

B O O N , N O R T H C A R O L I N A

Schilbrack, Kevin. ( 2016) 'Theorizing

Religion and the Role of Philosophy,"

Method and Theory in the Study of

Religion Version of record available

from Brill Academic Publishers, http://

www.brill.com/. [ISSN 0943-3058] 


\title{
Theorizing Religion and the Role of Philosophy
}

\author{
Kevin Schilbrack \\ schilbrackke@appstate.edu
}

\begin{abstract}
This paper is a response to Patrick Hart's "Theory, Method, and Madness in Religious Studies," and it argues that philosophy is presupposed and therefore ineliminable when theorizing religions.
\end{abstract}

I come to the academic study of religions as a philosopher, and I notice often that the relationship between the work of philosophy and that of the other disciplines in our field is poorly understood. Philosophers typically pursue normative questions. They seek to distinguish what is real from what merely appears real, views that one should hold from beliefs that are unjustified, and what is just from what is oppressive. A class on ethics, for example, seeks to distinguish what is morally right from what is merely prudent. But whether such normative questions fit in the academic study of religion — and, if so, how - is a topic that is murky and contested. I therefore read Patrick Hart's insightful paper about the history of the concepts of "method" and "theory" with interest. He helps me ask this question: how do the normative questions pursued by philosophers relate to the way that these two concepts are now understood in our field?

The answer, apparently, is that philosophy is accepted as a method, but does not clearly have a place when scholars theorize religion. This division is, I judge, an unhealthy arrangement. 
Hart shows that philosophy has long been spoken of as a method. Plato and Aristotle both describe the practice of philosophy in this way (pp. 8-10). And Hart speaks for the general consensus that the academic study of religions is a polymethodical or multidisciplinary field that includes philosophy when he cites Russell McCutcheon, saying: "Scholars in the study of religion apply historical, archaeological, linguistic, textual (e.g. philological, structural and semiotic), philosophical, sociological, psychological, ethnographic, anthropological and art historical methods" (pp. 13-14). More precisely speaking, we should refer to philosophy not as "a" method but rather as a set or a family of related methods. The pragmatic method in philosophy seeks to clarify conceptual disagreements by turning attention to the experiential difference, if any, that can be found between two rival accounts. The deconstructive method takes meanings that are unreflectively taken as real and seeks to reveal them as conceptual constructs, historically emergent and ideologically motivated. The phenomenological method seeks to bracket the scholar's distorting assumptions in order to give an accurate description of the objects of experience. The genealogical method seeks to give an account of the constitution of knowledges or discourses, especially concerning those aspects of our lives (like sexuality or insanity) that are assumed to be historically stable. All of these philosophical methods, and others, have been put to use in the academic study of religions. Granted that there is disagreement within pragmatism and within each of these other movements about what its method properly is, and granted that some of these approaches have resisted being called a method, it is fair to say both (i) that philosophers often understand themselves as employing a method and (ii) that such methods have found a place in the academic study of religions.

One might expect that the same would true of the term "theory." As Hart shows, Plato and Aristotle also described philosophy as theoretical, using the term to mean seeking true sight or knowledge of the nature of things. Certainly, contemporary philosophers use the term all the time: "Ethical Theory" and "Theories of Knowledge" are typical philosophy courses and textbooks.

But when one turns to theories of religion-whether in capstone courses or textbooks (or this journal!) - philosophers are found few and far between. None of the classical theorists of religion (Tylor, Frazer, Marett, Freud, Jung, Durkheim, Weber, Eliade, or Geertz) are philosophers. And the same is true of the contemporary theorists of religion (Berger, Bellah, Parsons, Stark and Bainbridge, J. Z. Smith, Tweed, Lincoln, Luhmann, or Vázquez). So, scholars in the academic study of religion accept philosophy as one method (or set of methods) in the field-perhaps in its own self-imposed ghetto, "philosophy of religion." But when scholars theorize religion, apparently philosophy falls out. 
This absence is clarified when Hart identifies the three kinds of "theory in religious studies" (pp. 19-20). The first kind of theorizing concerns the origin of religion. One sees this "grand" theorizing in Tylor's speculation that religion emerged as an attempt to understand the apparitions of the deceased in dreams and the difference between an animated person and the dead body, or in Durkheim's claim that religion began with the totemic apotheosis of society. The second kind of theorizing in religious studies seeks to provide an account that explains religious phenomena by pointing out their naturalistic causes. Most of the classical and contemporary theorists listed above fit this description. There are then critics of these two kinds of theories, critics like Tomoko Masuzawa who seek to critique or undermine those earlier theoretical projects. Using McCutcheon's distinction between "theory-as-explanation" and "theory-as-critique," Hart suggests that these critics are themselves offering a new explanatory theory, namely, one that seeks to explain not religion but "religion." Whether or not Hart is right about this (and he is wrong to take McCutcheon as an ally on this point, since McCutcheon now distinguishes critique from theory [2013:347]), one can see that none of these three approaches includes what philosophers typically do.

The danger here, to my mind, is that those who study religions will come to think that the normative questions pursued by philosophers are unscientific or acritical or confessional or "theological" in a pernicious sense, and that those questions therefore don't belong in the academic study of religion. Moreover, the lack of philosophy in theorizing religion may spill over into method. Bruce Lincoln's “Theses on Method" were first published in this journal almost 20 years ago and have since been widely reprinted. Hart says that Lincoln's theses are not really about method for our field per se, but rather about historical method in particular (p. 15), and I think that he is right. But the broad title of Lincoln's piece has probably given many the sense that the theses aim to articulate the ground rules for method in the academic study of religions as such. And the theses themselves suggest this when they speak of the virtues that define not just the historian, but any scholar (thesis 5 ) and identify conditions without which one fails to be a scholar at all (thesis 13). I find Lincoln's view of the historical method a bracing sketch of what critical explanation of religions should be, but I wonder whether the absence of philosophy in theories of religion now gives many of my colleagues the sense that the proper method in the academic study of religions also sets aside normative questions. As Lincoln once told me, in the academic study of religions, we do not tell students what is right or wrong.

My own view is that the academic study of religion cannot excise normative questions, and therefore the subject matter of philosophy cannot be 
eliminated from the field. For example, what Hart calls theory-as-explanation rests upon views of what constitutes a real cause and what the human mind can know - typically views inherited from empiricist philosophers. What Hart calls theory-as-critique rests upon views of how language operates and how it relates to the world - typically views inherited from post-structuralist philosophers. Marxist theory of religion presupposes Feuerbach's philosophical anthropology. Critical theory of religion inherits Nietzsche's hermeneutics of suspicion. Durkheim is a Kantian; Eliade gets religious being-in-the-world from Heidegger; and Geertz steals from Ricoeur and Wittgenstein. When scholars theorize religion, they do so in ways that are dependent on the normative views on which philosophers critically reflect (for more on this, see Schilbrack 2014: esp. ch. 7). In fact, when any scholars theorize anything, they presuppose answers to normative questions about what is real, true, moral, or just.

If I am right about the ineliminability of philosophy from theory, it does not follow that a capstone course in theories of religion needs to add a philosophical theory of religion to complement those of Freud, Marx, and Durkheim. But it does mean that the trend of thinking that the study of religions is resolutely scientific or that it can operate without raising questions about values or reality is confused. I therefore hope that theory of religion in future capstone courses or textbooks (or this journal) treats theorizing in a way that acknowledges and does not hide the fact that it always requires one to have answered normative questions.

\section{References}

McCutcheon, Russell T. (2013). A modest proposal on method. Method and Theory in the Study of Religion 25(4-5): 339-349.

Schilbrack, Kevin (2014). Philosophy and the Study of Religion: A Manifesto. Malden: Wiley-Blackwell. 